\title{
Differences between linguists and subject-matter experts in the medical translation practice:
}

\section{An empirical descriptive study with professional translators ${ }^{1}$}

\author{
Ana Muñoz-Miquel \\ Universitat Jaume I
}

In the literature on medical translation, the question as to who translates (or should translate) medical texts has been largely discussed on the basis of the traditional linguists versus subject-matter experts opposition. Both scholars and professional translators have attempted to determine medical translators' profile by making statements about the characteristics of translators with a linguistic background and those of translators with a scientific-medical one. These statements are generally based on intuition or personal experience rather than on empirical data which can be used to back up any kind of evaluation that may be made. This paper aims to bridge this gap by presenting the results of an empirical descriptive study which surveyed practicing medical translators. The survey included questions such as academic qualification, years of experience, customers, genres translated, main difficulties encountered, and degree of self-instruction received, among others. On the basis of these data, this paper approaches the medical translators' profile and explores the main differences between translators with a linguistic background and translators with a scientific-medical one. The results show that some of the most substantial differences between them relate to the years of experience, difficulties encountered, documentation resources used, and training needs.

Keywords: medical translation, professional practice, translators with a linguistic background, translators with a scientific-medical background, empirical descriptive study

\section{Introduction}

\footnotetext{
${ }^{1}$ This study was conducted within the framework of the project entitled Análisis de necesidades y propuesta de recursos de información escrita para pacientes en el ámbito de la Oncología (FFI2012-34200), funded by the Spanish Ministry of Economy and Competitiveness.
} 
One of the oldest types of translation is that which deals with medicine. Since ancient times, it has played a major role in the construction and dissemination of medical knowledge (Montalt Resurrecció 2010, 72). Nowadays, medical translation is crucial for the proper development of communication and knowledge in areas such as health care, patient education, health promotion, clinical research, drug development or medical practice, among others. Huge amounts of medical-healthcare information, which needs to be translated, are generated daily in a wide variety of contexts: international health organisations, pharmaceutical laboratories, medical publishers, research centres, hospitals, universities, health institutes, contract research organisations (CROs), etc. Thus job opportunities and career development possibilities for translators in the medical-healthcare field are considerable.

Medical and health professionals with language skills have been those traditionally in charge of carrying out medical translations since Translation Studies at university level are relatively recent (Navarro and Hernández 1997; Montalt Resurrecció 2007). This situation started to change with the creation of translation degrees and, in the last few years, with the development of the first postgraduate programmes which focus exclusively on medical translation (Montalt Resurrecció 2007; Muñoz-Miquel 2014a); witness, for example, the Master's Degree in Medical and Healthcare Translation of the Universitat Jaume I in Spain, which has been training future medical translators since 2007. Thus, we assume that today both translators with a scientific or medical background (hereafter TSBs) and translators with a linguistic background (hereafter TLBs) meet the medical translation and communication needs.

Given this apparent variety of profiles, the academic literature has largely discussed the question of who translates (or should translate) medical texts and what competences they should have (competences being understood as the capacities, knowledge and skills possessed by professional translators; see Kelly 2002, 14). See, for example, Gile (1986), Rouleau (1994), Wakabayashi (1996), Balliu (1998), Lee-Jahnke (1998, 2001, 2005), Mayor Serrano (2003, 2006), Montalt Resurrecció and González-Davies (2007), Albarrán Martín (2012), Mugüerza Pecker (2012), and so on. Both scholars and professional translators have attempted to determine medical translators' profile and competences by providing opinions that arise mostly from a dichotomy that has led to intense discussions in the literature, namely, which professional is better suited to carry out this activity, the medical professional who also has linguistic knowledge, or the translator with extensive knowledge of medicine: 
Whether the experienced professional linguist with extensive knowledge of medicine (however acquired) will be able to prepare a better medical translation than the medical student or medical professional with a background in foreign language (however acquired) is a question that has long preoccupied not only educators [...] but also theorists of translation science and practicing translators pursuing a business career in medical translation. (Fischbach 1998, 4)

This traditional linguist versus subject-matter expert opposition has also been dealt with in other specialised translation fields in which acquiring thematic knowledge is of paramount importance, such as the legal or technical ones (Wright and Wright 1993; Gallardo San Salvador 1996; Félix Fernández and Alarcón Navío 1998; Gutiérrez Rodilla 1998; or Valderrey Reñones 2012, among others). ${ }^{2}$ Scholars such as Gouadec $(2007,231)$ have even suggested that there could be a certain kind of rivalry between these two profiles in the professional context: "Both have similar approaches and similar interests to defend [...] and should not be viewed as rivals in the profession."

The focal point of many of the existing contributions on medical translators' profile is the discussion of the strengths and weaknesses of TLBs and TSBs (e.g., see, Gile 1986; Rouleau 1994; Navarro and Hernández 1997; Balliu 1998; Lee-Jahnke 1998, 2001, 2005; Navascués Benlloch and Hernando Saudan 1998; O’Neill 1998; Robertson 1998; Alfaro 2009; Mugüerza Pecker 2012; etc.). Despite being undoubtedly interesting, these works are largely based on intuition or personal experience of either a professional or teaching nature, without being complemented with empirical data that reflect the features observed in professional translators (Mayoral Asensio 2001, 111); data which could be used as more objective evidence to corroborate any kind of judgement that may be made about the profile of medical translators. With very few exceptions (Jensen and Zethsen 2012; Muñoz-Miquel 2014a, 2014b, 2016), there are practically no studies that provide systematic data about who translates medical texts or what features characterise their professional practice.

This situation led us to ask the following questions: what is the academic and socioprofessional profile of medical translators, and are there any differences between TLBs and TSBs in terms of their professional practice or training needs? This paper aims to respond to

\footnotetext{
${ }^{2}$ These contributions include very different approaches: from authors who consider that translators should necessarily be subject-matter experts (physicians, lawyers, engineers, etc.) (Félix Fernández and Alarcón Navío 1998), to authors who think that collaboration between linguists and subject-matter experts is the best option (Wright and Wright 1993).
} 
these questions by presenting the results of an empirical descriptive study in which practicing medical translators were surveyed with a view to obtaining data about their profile and the practice of their profession. Based on the results obtained from the survey, this article explores the differences in medical translation practice according to the translators' academic profile; that is, the nature of the graduate degree that they have taken. The differences between TLBs and TSBs are, thus, presented and discussed. The final objective of this study is to collect empirical information that can help provide a better understanding of the group of professionals who satisfy the needs of such an important market niche, that of medical translation.

The paper is structured as follows: the methods used in the study are described in section 2; the results obtained are analysed in section 3; the main findings are discussed in section 4; and finally the most important conclusions and some future lines of research are presented in section 5 .

\section{Methods}

As mentioned above, this paper is based on an empirical descriptive research study with medical translators (167 in all, as we will explain in the following paragraphs). The translators under study had to meet two criteria: (1) doing medical translations, regardless of whether this activity was carried out on an exclusive basis or in combination with other tasks (either related specifically to translation or not); (2) working with the English-Spanish language pair, although not necessarily on an exclusive basis. Unlike other works in which the empirical study with translators is restricted to a geographical area (e.g., see Li 2000; Dam and Zethsen 2010; Sachinis 2011; Cerezo Merchán 2012; etc.), the criterion adopted in this case was the combination of languages, irrespective of the place where the translators lived or worked.

The English-Spanish language pair was chosen because, from our own professional, teaching and research experience, it is that which we know the best. However, we also considered that research into this language combination could be particularly relevant given both the importance of English (Pilegaard 1997; Navarro 2001; Montalt Resurrecció and González-Davies 2007) and Spanish (Instituto Cervantes 2014) in the field of international communication, and the substantial volume of medical translations from English into Spanish that is generated thanks to the role of organisations such as the World Health Organisation (WHO), the Pan American Health (PAHO) or European Union institutions, among others. 
The data collection method used was a survey, which is being increasingly employed in Translation Studies for exploring the social dimension of translation and the profiles of translators as social agents (Dam and Zethsen 2010, 195; Kuznik, Hurtado Albir and Espinal Berenguer 2010, 323; Saldanha and O'Brien 2013, 151). Unlike other methods such as interviews, using the survey allows the researcher to address a larger population sample rigorously, systematically and anonymously in order to obtain more quantifiable results (Hernández Sampieri, Fernández Collado and Baptista Lucio 2010), which can be generalised when probability sampling is carried out (Rea and Parker 2005).

The survey design was based on the results of a previous exploratory qualitative study (Muñoz-Miquel 2014a), in which 12 medical translators (seven TLBs and five TSBs) with different professional profiles (in-house translators, freelancers, etc.) were interviewed. The main topics and aspects that came up in the interviews gave rise to the principal variables to be measured in the present survey, the scales for measuring those variables, and the specific items. Despite not being the primary objective of the preliminary study, the obtained results yielded some interesting differences in several aspects of this professional practice (customers, training needs, genres translated, etc.) depending on the respondents' academic profile. This fact encouraged us to carry out the study presented in this paper for the purpose of exploring these differences by analysing quantitative data obtained from a much larger sample.

The instrument used to collect data was an online questionnaire, designed with the LimeSurvey survey management system. One of the main advantages of this programme is that it allows controlled access to the survey (only those people who have an entry and a unique token can access the questionnaire) while ensuring confidentiality of responses. These features prevent answers from being given by people who do not match the profile or the same translator from completing the survey more than once.

The validity of the questionnaire was tested by the evaluation of a panel of three experts and by a pilot test with five professional medical translators who fulfilled the characteristics of the target population. Three of them were TLBs and the other two were TSBs. They were all asked to assess aspects such as questionnaire length, flow of questions, wording of items, etc. The participants' suggestions and their responses to the questionnaire gave rise to some amendments: new items and questions were included, the wording of some questions was simplified to make them easier to understand, and some configuration errors were fixed. 
The survey questions (49 in all) involved different types of answers (single-option, multiple-choice, ranking, Likert-type scales, etc.), which covered a wide range of topics involving the medical translators' profile as a whole. However, and due to space restraints, this paper presents only the responses to those questions in which notable differences between TLBs and TSBs were found.

As the total population of medical translators was unknown, because no official figures for the number of medical translators in Spain or in other countries, are available, we were unable to perform probabilistic sampling to ensure the generalisation of the results. Therefore, convenience sampling (Rea and Parker 2005, 173; Saldanha and O'Brien 2013, 34; Kumar 2014, 244) was carried out by creating an ad hoc sample of potential respondents who fulfilled the characteristics of the target population. To do this, we used data from sources from which lists of translators specialised in the medical field could be obtained; that is, professional translator associations and directories. We took into account the ones specific to the medical field and others that work both nationally and internationally, and which allowed searches for translators according to medical specialisation and the English-Spanish language combination. Thus, we accessed Tremédica (International Association of Translators and Editors in Medicine and Allied Sciences), the ITI Medical \& Pharmaceutical Network, Asetrad (Spanish Association of Translators, Editors and Interpreters), Aptic (Association of Professional Translators and Interpreters of Catalonia), and Proz. Other participants in the study included lecturers and students who had previously taken the Master's Degree in Medical and Healthcare Translation at the Universitat Jaume I, together with members of the MedTrad medical translation forum.

The final sample consisted of 451 translators. The survey was sent out in June 2013, and data were analysed between July and October of that same year. The questionnaire was answered by 236 translators. Of those, 189 filled it in completely and 47 did so only partially, which gives a response rate of $52.3 \%$ if we take into account all the answered questionnaires, and of $41.9 \%$ if we consider only those completely filled in. We believe that these data are highly satisfactory if we bear in mind just how low - usually not higher than $20 \%$ - response rates to online questionnaires are (Kumar 2014, 181).

Answers were analysed using the IBM SPSS Statistics software package, version 21. The SPSS tools used were those typically employed for descriptive statistics (frequencies, descriptives, contingency tables). Despite the convenience sampling method used, we decided to complement the analysis with some inferential statistical tests, due to the relatively large sample of medical translators obtained. We resorted to Pearson Chi-squared tests and 
one-way analysis of variance (ANOVA) tests to analyse if the differences found between TLBs and TSBs were statistically significant. Chi-squared tests were used with qualitative variables and ANOVA tests were employed with quantitative variables (Rodríguez Sabiote, Gutiérrez Pérez and Pozo Llorente 2007). A p-value of .05 or below was considered to show a significant difference (Wood 2003, 124).

\section{Results}

This section analyses the results obtained. To make the analysis easier, they are presented in two blocks:

a. Socio-demographic data: this block includes information about training at both the graduate (the study's main variable) and postgraduate levels, as well as about gender, age and employment status.

b. Socio-professional aspects: this is the most important block of the analysis as it presents the main differences between TLBs and TSBs in terms of medical translation practice and perceived training needs. These differences concern aspects such as years of experience, reasons for entering the field, percentage of their work that entails medical translation, customers, genres translated, resources used, etc. The section concludes with a summary of the results obtained.

Before moving on to the analysis, it should be noted that there were translators who did not actually translate medical texts from English into Spanish, despite being categorised as working with that language pair in the professional directories and associations which we accessed. In order not to distort the results, these responses (22 in all) were excluded from the analysis. Therefore, the data provided below correspond to a sample of 167 translators.

\subsection{Socio-demographic data}

Figure 1 shows the type of graduate-level education that the respondents had received: 


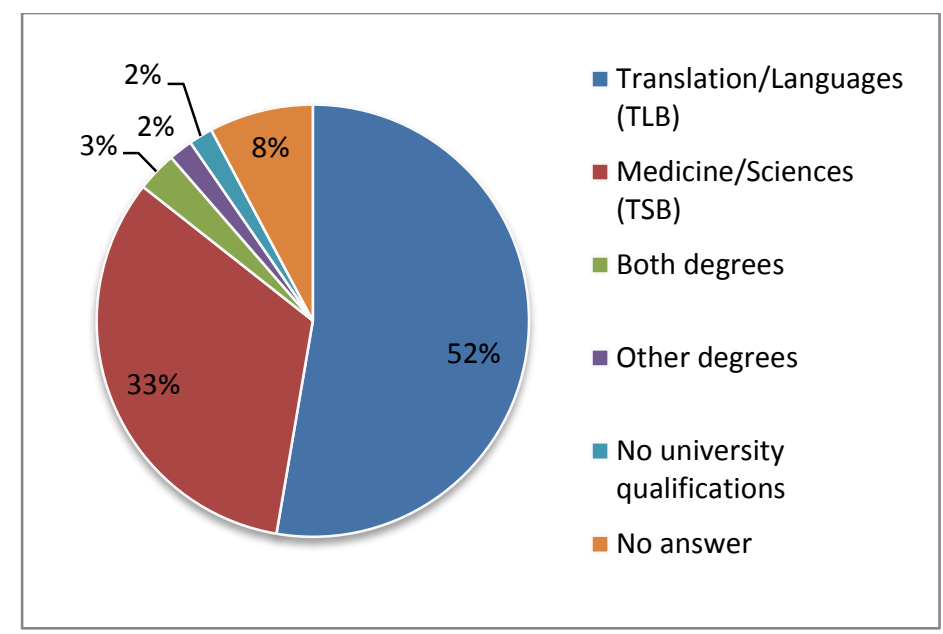

Figure 1. Graduate-level education received

As we can see, what we call TLBs predominated; that is, the group that embraces those who studied Translation and Interpreting (or related), or Philology (or related), and those who marked a degree related to the arts in the 'Other degrees' survey option. A considerable number (33\%) included TSBs; that is, they had studied one of the science degrees offered as a response to the question (Medicine, Biology, Pharmacy, Veterinary Science, and Engineering) or another degree related to science that was not included in the provided options. Five translators (3\%) had both a linguistic and scientific background (e.g., they had studied both Translation and Interpreting, and Biology). Finally, a small percentage indicated situations other than those outlined above: (1) they studied other degrees; (2) they had no university qualifications or had not finished their studies; (3) they did not state what graduate level of training they had taken. It should be noted that in order to analyse the differences between TLBs and TSBs, we took into account the group of translators who had received only scientific or medical training (33\%) and the group of translators who had received only linguistic/translation training $(52 \%)$. The other profiles identified (translators with both science and linguistic degrees, translators with other kinds of degrees, and translators with no university education) were not considered because they represented a very small number of respondents.

The qualification that clearly predominated in the TLB group (see Figure 2) was Translation and Interpreting (TI), and the second commonest, be it a long way behind, was Philology. The remainder had either both qualifications or others (such as Journalism). 


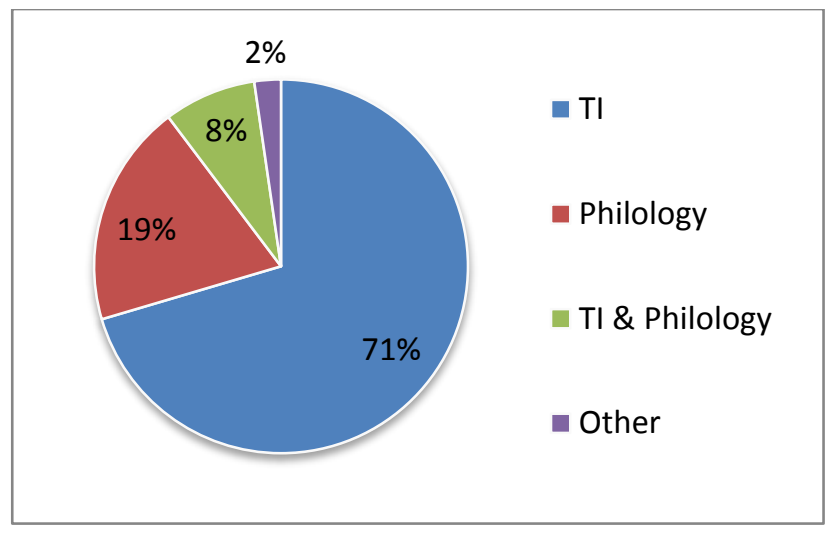

Figure 2. Translation-related qualifications

The predominant qualifications among TSBs (Figure 3) were degrees in Medicine, followed closely by those who studied Biology. The other qualifications included in the options were found much less frequently. Only $7 \%$ stated having studied other qualifications not included in the questionnaire, such as Scientific Computation. Hence, Translation and Interpreting, Medicine, and Biology were, and in that order, the commonest qualifications among the translators in our study sample.

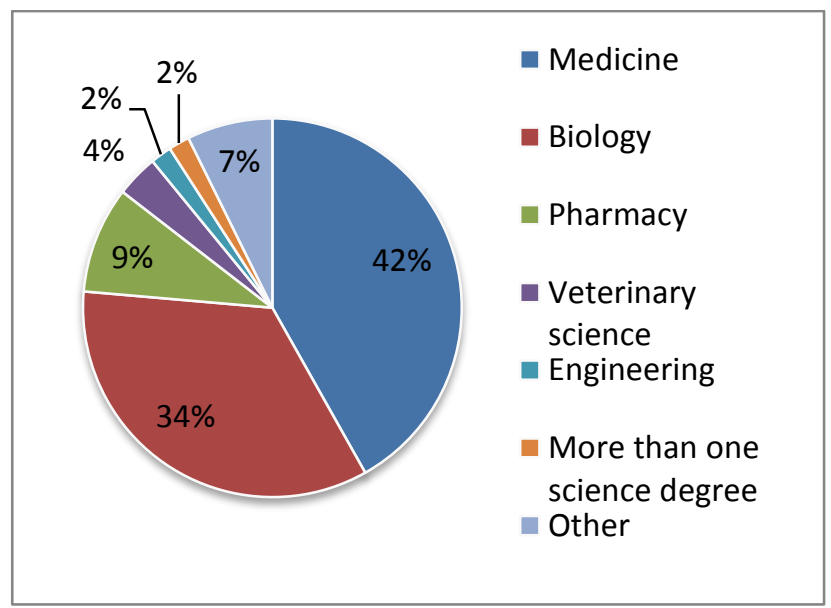

Figure 3. Science-related qualifications

As regards postgraduate training, over half the respondents (51\% of TLBs and $56 \%$ of TSBs) had a degree of this kind. Figure 4 shows the proportion of TLBs and TSBs with postgraduate training related with Translation/Philology or Medicine/Sciences: 


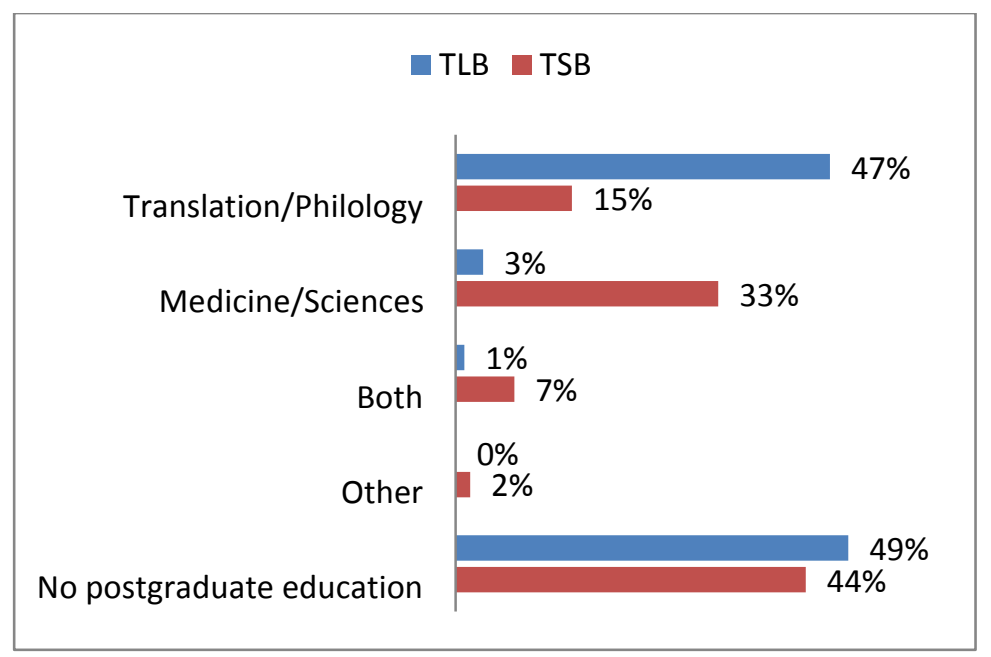

Figure 4. Postgraduate-level education received

The results obtained, which are statistically significant (Chi-squared $p$-value $=.000$ ), show that a higher proportion of TSBs completed their training with a postgraduate degree in Translation or Philology (15\%) than the TLBs with a postgraduate degree in Medicine or Related Sciences (3\%). These results could suggest that while science postgraduate degrees are more restricted to scientific profiles, translation qualifications are generally more open to a wider variety of profiles. It is also noteworthy that despite the very small number (only five people in all), there were also translators with a postgraduate education of both kinds.

Regarding the respondents' gender, Figure 5 shows the differences between TLBs and TSBs (Chi-squared $p$-value $=.000)$ :

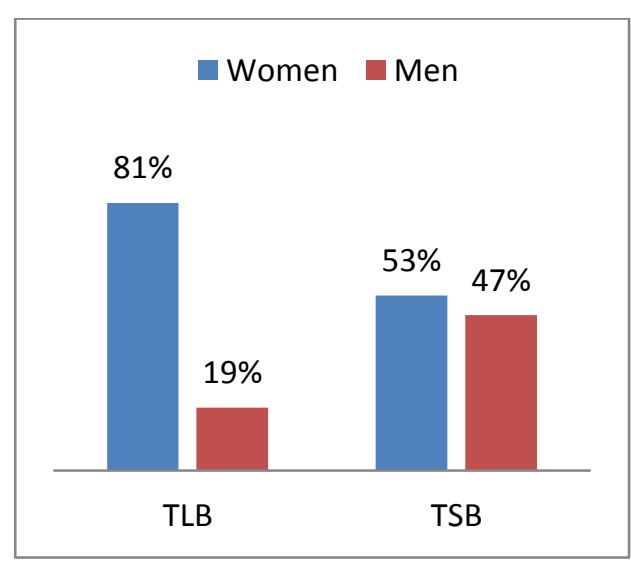

Figure 5. Gender

The figures that correspond to the TLB group confirm the traditional image of the translation profession in general, in which females predominate (Pym et al. 2012, 3). In the TSB group, the proportion of women and men is similar, which could indicate that there is not a clear 
predominance of one gender over the other in medical sciences degrees (at least in those studied by the translators in our sample).

As far as age is concerned, the mean age for the whole study sample was 43 ; the youngest respondent was 23 years old and the oldest was 71. In the TSB group, the mean age was significantly higher than that of the TLB group: 49 versus 41 years old (ANOVA $p$-value $=.000)$.

Finally, regarding employment status, most translators stated that they were freelancers, which is the commonest employment status in the translation profession (Pym et al. 2012, 3). Only $12 \%$ of the total sample were in-house translators. Figure 6 shows the results distributed according to the respondents' academic profile:

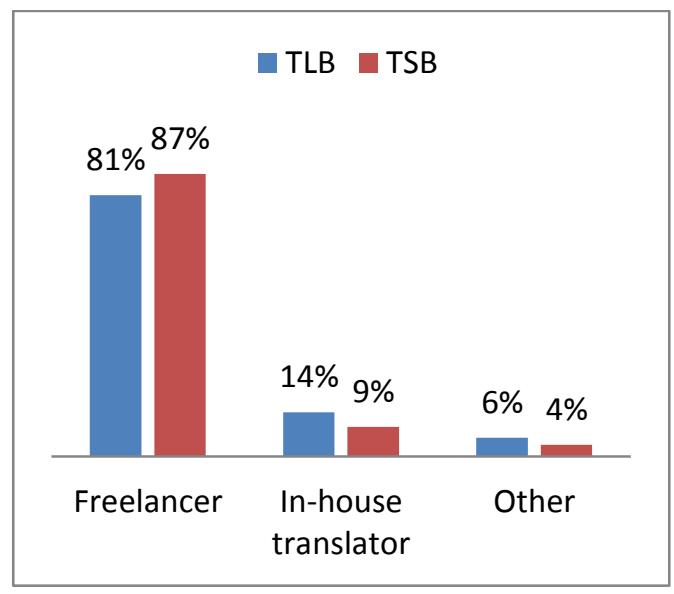

Figure 6. Employment status

As we can see, the results are similar in both groups, and the statistical tests show that the small differences between TLBs and TSBs are not significant (Chi-squared $p$-value $=.574)$. It should be noted that among the translators who answered the 'Other' option in both groups, there were professionals whose main occupation was not related specifically to translation (employers in an international department, quality managers, etc.).

\subsection{Socio-professional aspects}

As noted above, this block presents the differences between TLBs and TSBs in terms of certain aspects of their medical translation practice. This is divided into 10 sub-sections that match different aspects of the respondents' socio-professional profile. ${ }^{3}$

\footnotetext{
${ }^{3}$ Other aspects that were addressed by respondents and for which we did not find any difference between TLBs and TSBs, concern the topics translated or language combinations, among others.
} 


\subsubsection{Years of experience}

One of the most substantial differences between TLBs and TSBs lies in years of experience in translating medical texts. In the field of expertise studies (Bloom 1985; Ericsson 1996), expertise is often taken to correlate directly with the time spent in a given professional practice on a regular basis, with a 10-year rule as a threshold across several domains (Muñoz Martín 2014, 5), such as algebra, physics, psychology, translation, etc. By taking this threshold as a basis, and in order to find out which group of translators had more years of experience, we divided the sample into two major groups: ${ }^{4}$

a. Those with more than 10 years of continued professional practice translating medical texts.

b. Those with less than 10 years of experience.

As Figure 7 shows, $73 \%$ of translators who had more than 10 years of experience had a scientific or medical background, while the majority of translators with a linguistic background had significantly less experience in translating medical texts (Chi-squared $p$ value $=.000)$.

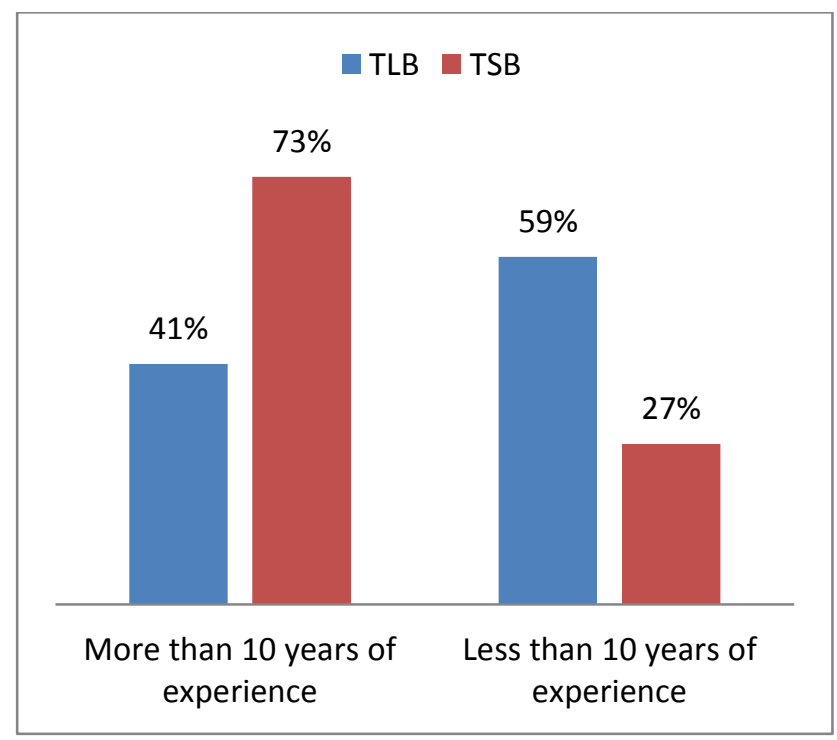

Figure 7. Years of experience

These results indicate that the translators who studied a medical or science degree have been working in this speciality for more years. Therefore, as expected, they occupied this professional niche earlier than those who studied a Translation or Philology degree.

\footnotetext{
${ }^{4}$ It should be taken into account that classifying respondents into these two main groups may involve some limitations because for professional practice to be considered "continued", other factors than those considered in this study could play a part (see Shreve 2006).
} 


\subsubsection{Reasons for entering the medical translation field}

The main reason why translators in the sample began to translate texts belonging to the medical field differs significantly (Chi-squared $p$-value $=.000$ ) among the groups studied (see Figure 8):

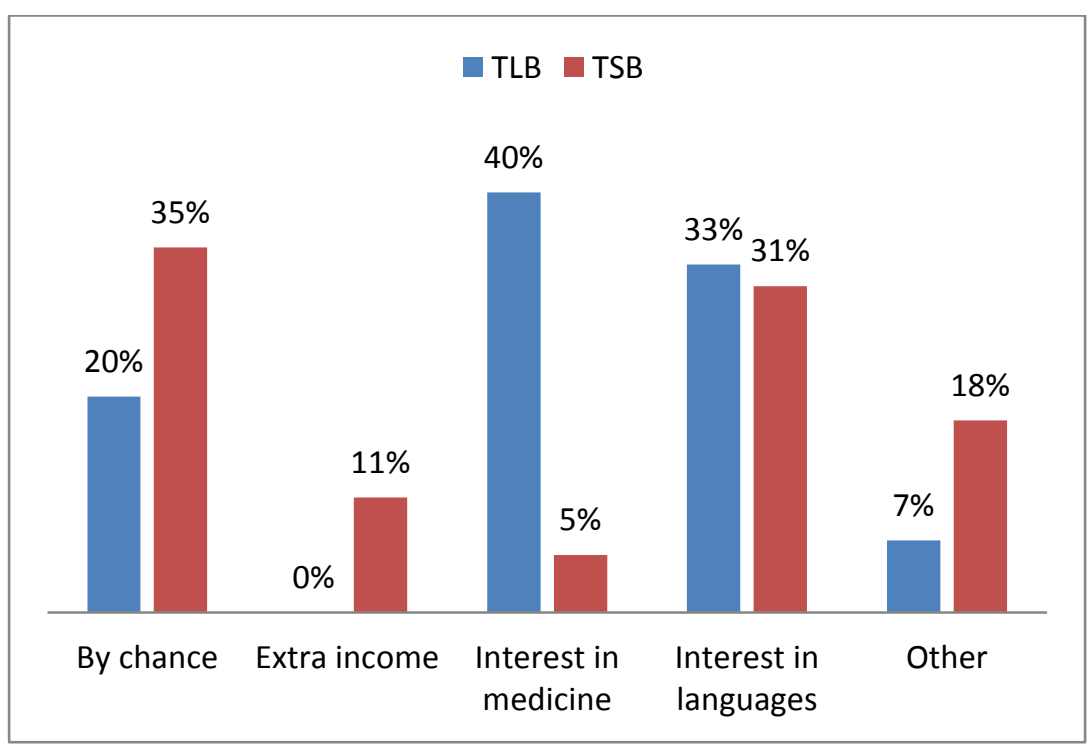

Figure 8. Reasons for entering the medical translation field

Regarding TLBs, Figure 8 shows that, although a far-from-negligible $20 \%$ of TLBs started to translate medical texts incidentally, the majority who entered the medical translation field were moved by their interest in medicine and related sciences and, obviously, by their interest in languages and translation. These results indicate that for those with a linguistic background, translating texts from the medical field is, to a certain extent, quite vocational, as the results suggest that medical translation always attracted their attention.

The results for TSBs also show a vocational component in their professional choice since $31 \%$ were moved by their interest in languages/translation. Nevertheless, the fact that most TSBs accessed the medical translation field simply by chance, and that $11 \%$ did so to earn extra income, confirms that professional translation practice is not the 'natural' career of those who studied a science or medicine degree.

\subsubsection{Percentage of work that entails medical translation and combination with other} professional activities

Another significant difference lies in the percentage of work activity devoted exclusively, or almost exclusively (at least $75 \%$ of working hours), to medical translation. According to our 
study, more than half the TSBs $(55 \%)$ work only on medical translation, versus $26 \%$ of TLBs, who usually receive more diversified jobs and also perform other activities (Chisquared $p$-value $=.001)$.

The types of activities that are combined with medical translation are shown in Figure 9.

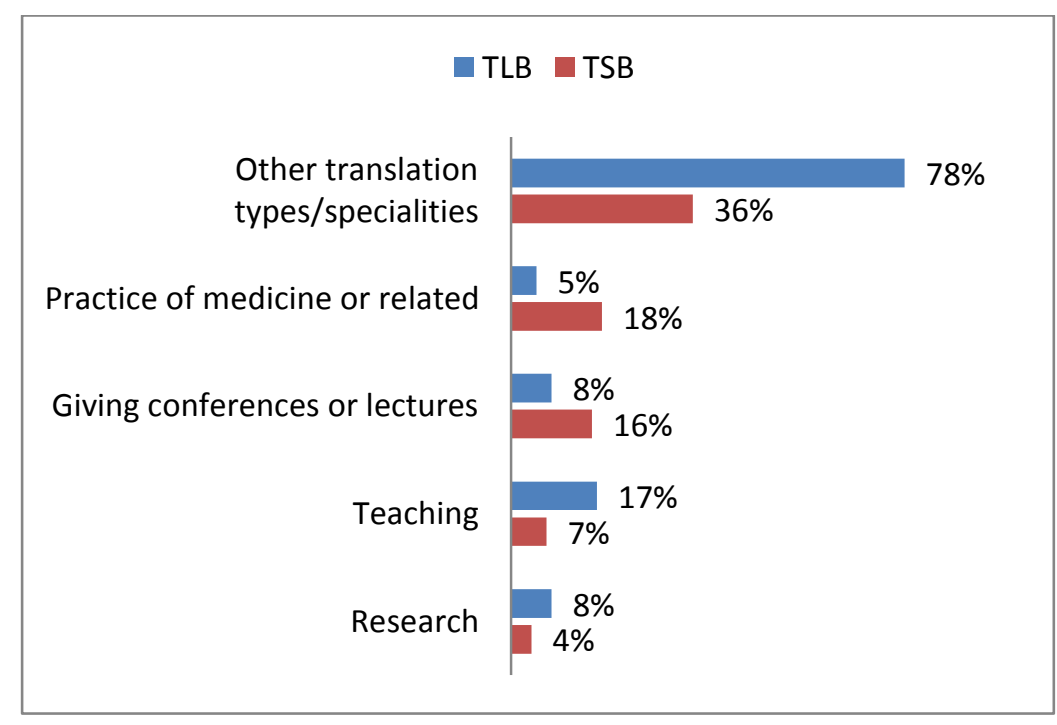

Figure 9. Other professional activities carried out

Although the activity that both groups of translators most frequently perform is the translation of other specialised areas, the proportion of TLBs who do so is significantly higher than in TSBs (Chi-squared $p$-value $=.000),{ }^{5}$ a result which agrees with the findings set out above. Figure 9 also shows that a far-from-negligible percentage of TSBs combines translation with the practice of medicine (Chi-squared $p$-value $=.008)$, which reflects that translation is not their main activity. As regards other activities, results show that more TLBs combine translation with teaching $($ Chi-squared $p$-value $=.094)$ and research $($ Chi-squared $p$ value $=.301)$ and more TSBs give conferences or lectures on a topic (Chi-squared $p$-value $=$ $.121)$. However, as the $p$-values show, these differences between groups are not statistically significant.

\subsubsection{Other types of translation}

\footnotetext{
${ }^{5}$ As this was a multiple-choice question and the proportion of translators in each group does not necessarily add up to $100 \%$, a Chi-squared test was carried out for each answer. The same applies in sections 3.2.4, 3.2.5, 3.2.6, 3.2.9 and 3.2.10.
} 
The TSBs in our sample who do not translate medicine on an exclusive basis translate mainly scientific or technical texts, as shown in Figure 10. The TLBs who do not translate medical texts full-time do all the types of translation included in the options provided (scientific, commercial, technical, audiovisual, legal, etc.), including interpreting.

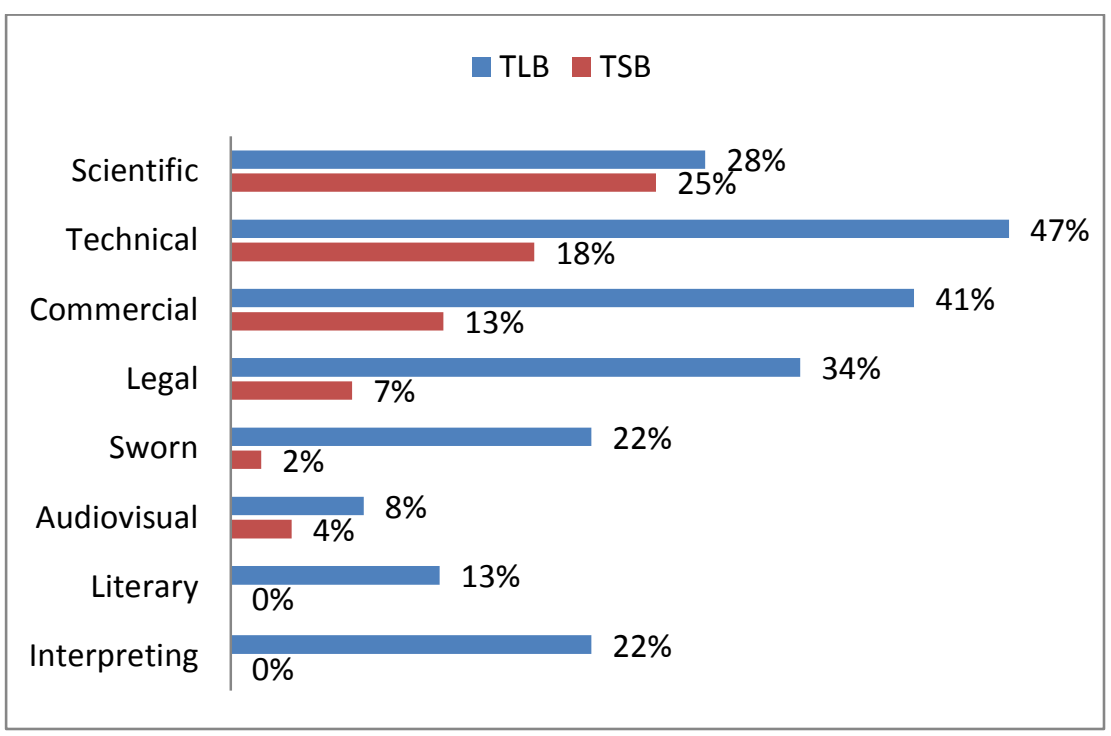

Figure 10. Types of translation translated

A more detailed analysis of these results reveals that TLBs mainly translate texts that correspond to the technical, commercial, legal, and scientific fields. Fewer TLBs, however, carry out literary and audiovisual translations, areas which have possibly fewer traits in common with medical translation given their more creative nature or the characteristics of the genres translated, among others. The percentage of TSBs who translate other fields than scientific or technical ones is very low, and is even non-existent in literary translation and interpreting. The Chi-squared tests show that the differences between the two groups for all types of translation are significant (the highest $p$-value was .006), except those related to the scientific $(p$-value $=.700)$ and audiovisual $(p$-value $=.301)$ types.

\subsubsection{Customers}

Figure 11 shows the type of customers that translators work for: 


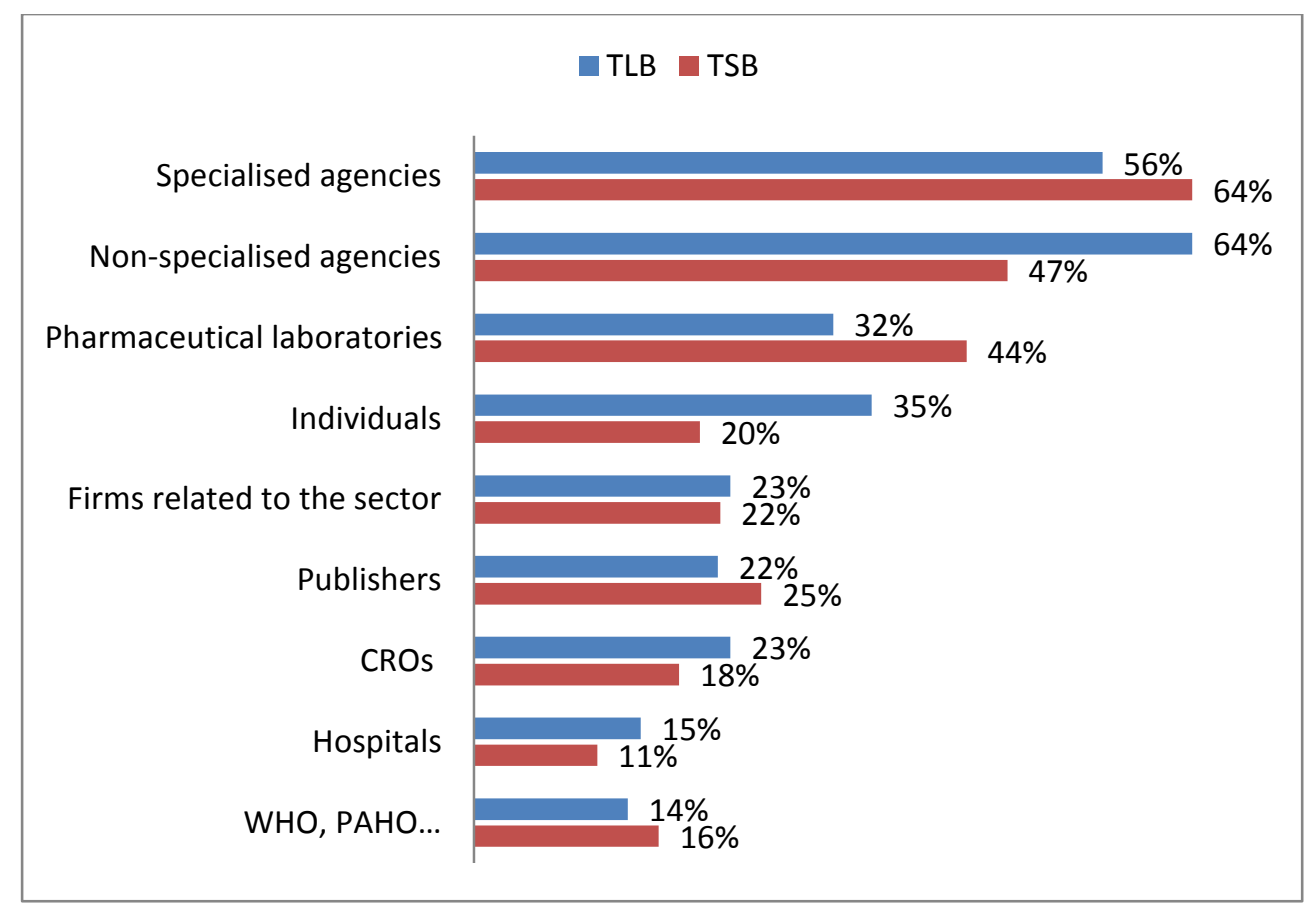

Figure 11. Types of customers

As we can see, both TLBs and TSBs work for a wide variety of customers, from translation agencies to international health organisations, such as WHO and PAHO. There are, however, differences between them. On the one hand, the proportion of TSBs who work for pharmaceutical laboratories and for translation agencies that are specialised in the medical field is higher than that of TLBs, although not statistically (Chi-squared $p$-values $=.153$ and .347, respectively). On the other hand, more TLBs work for individuals (doctors, pharmacists, patients, etc.) and for translation agencies that do not specialise in the medicalhealthcare sector. These differences are, once again, not statistically significant, although the values in these cases are closer to .05 (Chi-squared $p$-values $=.052$ and .054 , respectively).

Regarding other types of customers, the differences between groups are less substantial and not statistically significant, although we can see that more TSBs work for medical publishing houses $($ Chi-squared $p$-value $=.594)$ and more TLBs translate for CROs $($ Chi-squared $p$-value $=.516)$.

\subsubsection{Text genres}

Table 1 shows the list of genres included in the questionnaire and the proportion of TLBs and TSBs that translates each genre. The most substantial differences in terms of proportion of translators are colour-highlighted: the rows in blue indicate the genres translated in a higher proportion by TLBs; the rows in red are those in which the percentage of TSBs participating 
is higher. Note that the percentages in the TLB and TSB columns do not add up to $100 \%$. This is because each translator could choose more than one genre, indeed up to a maximum of three. Medical genres are listed alphabetically.

Table 1. Medical text genres translated

\begin{tabular}{|c|c|c|}
\hline Text genres & TLB & TSB \\
\hline Abstracts & $20 \%$ & $13 \%$ \\
\hline Advertising documents & $8 \%$ & $7 \%$ \\
\hline Anatomical atlases & $1 \%$ & $2 \%$ \\
\hline Case reports & $2 \%$ & $2 \%$ \\
\hline Clinical guidelines & $3 \%$ & $4 \%$ \\
\hline Clinical trial reports & $8 \%$ & $2 \%$ \\
\hline Clinical trial protocols & $32 \%$ & $36 \%$ \\
\hline Core data sheets & $13 \%$ & $13 \%$ \\
\hline Fact sheets for patients & $11 \%$ & $9 \%$ \\
\hline Informed consent documents (for clinical trials) & $32 \%$ & $18 \%$ \\
\hline $\begin{array}{l}\text { Informed consent documents (for surgery or } \\
\text { diagnosis) }\end{array}$ & $11 \%$ & $9 \%$ \\
\hline Instruction manuals of medical devices & $19 \%$ & $16 \%$ \\
\hline Market research documents & $3 \%$ & $2 \%$ \\
\hline Marketing authorisation applications & $6 \%$ & $9 \%$ \\
\hline Medical records & $1 \%$ & $5 \%$ \\
\hline Medical reports & $0 \%$ & $2 \%$ \\
\hline Medical treatises/manuals & $3 \%$ & $7 \%$ \\
\hline Others & $6 \%$ & $5 \%$ \\
\hline Patents & $3 \%$ & $5 \%$ \\
\hline Patient information leaflets & $7 \%$ & $7 \%$ \\
\hline Popularising articles & $14 \%$ & $9 \%$ \\
\hline Press releases & $6 \%$ & $9 \%$ \\
\hline Protocol amendments & $9 \%$ & $13 \%$ \\
\hline Quality of life questionnaires & $10 \%$ & $4 \%$ \\
\hline Research articles & $18 \%$ & $13 \%$ \\
\hline
\end{tabular}




\begin{tabular}{|lll|}
\hline Review articles & $2 \%$ & $4 \%$ \\
\hline Standard operating procedures & $0 \%$ & $2 \%$ \\
\hline Summaries for patients & $5 \%$ & $2 \%$ \\
\hline Summaries of product characteristics & $10 \%$ & $11 \%$ \\
\hline Textbooks & $5 \%$ & $15 \%$ \\
\hline Web sites & $5 \%$ & $5 \%$ \\
\hline
\end{tabular}

Although both groups translate a wide variety of genres (from core data sheets to review articles), TLBs in our sample translate the genres that address the general public to a greater extent, such as informed consent documents, quality of life questionnaires or popularising articles, and the genres that can be found in other types of translation, such as abstracts. More TSBs translate the genres belonging to the publishing sector and those that generally address specialists, such as textbooks, medical records, manuals or treatises. Despite these differences in the proportion of both groups of translators, the Chi-squared tests show no significant differences between them (the lowest $p$-value was 0.72 for informed consent documents for clinical trials and the highest was .968 for core data sheets). The exception are textbooks ( $p$ value $=.036$, which, as already mentioned, are mostly translated by TSBs.

\subsubsection{Main difficulties encountered}

Unlike the aspects analysed so far, which correspond to single-option or multiple-choice questions, the biggest difficulties for translators were evaluated on a 5-point Likert scale (1: I never find it difficult; 5: I always find it difficult). Once again, the results provide differences between TLBs and TSBs (Figure 12).

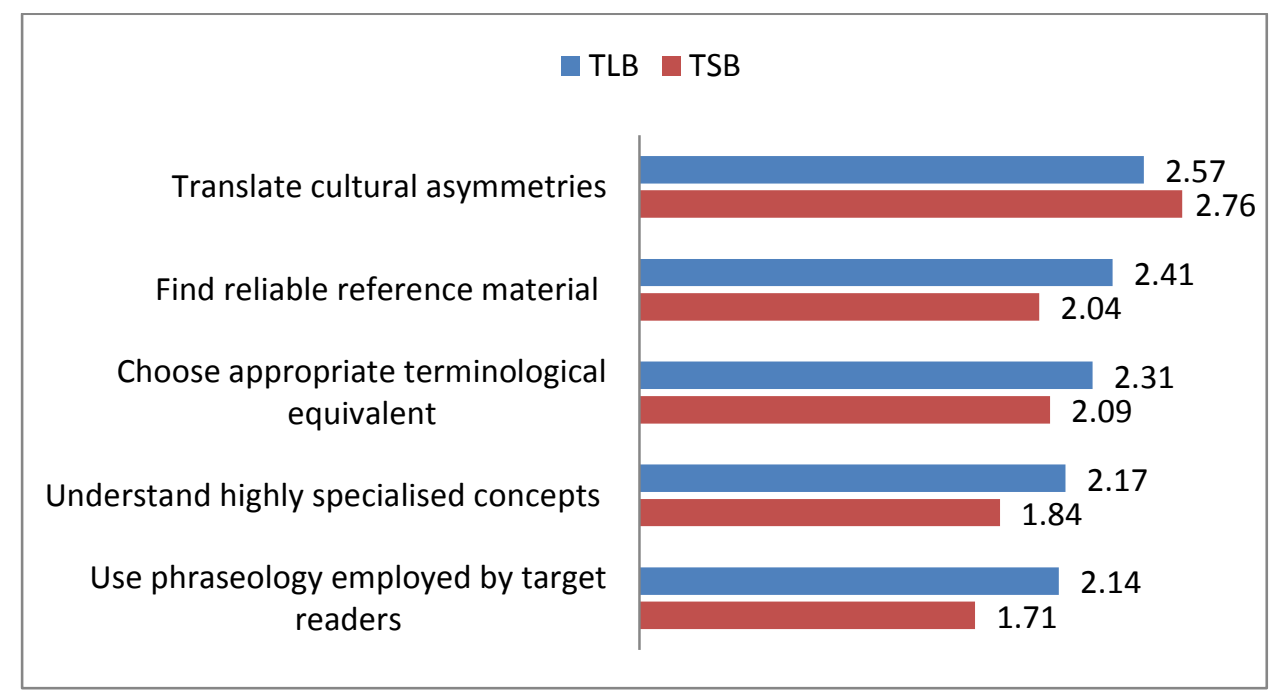


Figure 12. Medical translation aspects that present the greatest difficulty

Except for the translation of cultural asymmetries, TLBs find all the problems specified in the question significantly more difficult to solve than TSBs: understanding specialised concepts (ANOVA $p$-value $=.001$ ), using the phraseology and forms of expression employed by target readers $($ ANOVA $p$-value $=.002)$, finding reliable reference material (ANOVA $p$-value $=$ .010 ), and choosing the appropriate terminological equivalent according to the context (ANOVA $p$-value $=.047)$. TSBs, however, state that they have more difficulties when translating the asymmetries that derive from differences between the healthcare cultures implied (e.g., names of drugs, medical posts, beliefs about health and sickness, etc.), ${ }^{6}$ although in this case no significant difference between groups was found (ANOVA $p$-value $=$ $.262)$.

\subsubsection{Documentation resources used}

In order to determine which documentation resources are most commonly used, translators were provided with a list of all kinds of resources. They had to rate their frequency of use on the same Likert scale as that used in the previous question (1: I never use it; 5: I always use it). Table 2 shows that practically all the resources included in the options are consulted, on average, between often and very often (scores between 3 and 4). Among them, specialised bilingual dictionaries, resources created by the translators themselves (such as glossaries, translation memories or terminological records), specialised glossaries and monolingual dictionaries are the most commonly used, independently of the translators' academic profile.

The results reveal differences between the TLB and TSB groups. As before, the blue rows indicate the resources used in a higher proportion by TLBs, and the red ones denote those more widely used by TSBs.

Table 2. Documentation resources used

Documentation resources

\begin{tabular}{|lll|}
\hline Bilingual dictionaries (e.g., Navarro's Libro rojo) $^{7}$ & 4.38 & 4.47 \\
\hline Own resources & 3.91 & 3.98 \\
\hline
\end{tabular}

\footnotetext{
${ }^{6}$ These were examples that we provided in the questionnaire to illustrate this kind of difficulty.
${ }^{7}$ We refer to the Diccionario de dudas y dificultades de traducción del inglés médico ( $3^{\text {rd }}$ edition) (Dictionary of

${ }^{6}$ These were examples that we provided in the questionnaire to illustrate this kind of difficulty.
${ }^{7}$ We refer to the Diccionario de dudas y dificultades de traducción del inglés médico ( $3^{\text {rd }}$ edition) (Dictionary of doubts and difficulties in English medical translation) by Fernando A. Navarro.
} 


\begin{tabular}{|c|c|c|}
\hline Glossaries & 3.80 & 3.56 \\
\hline Monolingual dictionaries (e.g., Stedman, DTM) ${ }^{8}$ & 3.52 & 3.53 \\
\hline Parallel texts & 3.72 & 2.93 \\
\hline Medical databases (e.g., Pubmed) & 3.48 & 3.24 \\
\hline $\begin{array}{l}\text { Documents of official organisations (e.g., EMA, }{ }^{9} \\
\left.\text { ICD },{ }^{10} \text { INN) }\right)^{11}\end{array}$ & 3.34 & 3.44 \\
\hline Medical translation journals (e.g., Panace@) & 3.19 & 3.20 \\
\hline Conceptual works (medical manuals, treatises) & 3.18 & 3.15 \\
\hline Medical portals (e.g., MD Consult) & 3.13 & 2.51 \\
\hline Customers' translation memories & 3.11 & 2.75 \\
\hline Answers in translator forums & 2.94 & 2.78 \\
\hline Advice from subject-matter experts & 3.02 & 2.38 \\
\hline Advice from other colleagues & 2.99 & 2.47 \\
\hline Medical thesauri (e.g., MeSH) & 2.68 & 2.49 \\
\hline Biomedical search engines (e.g., BioMedSearch) & 2.75 & 2.27 \\
\hline Specialised corpora & 2.58 & 2.42 \\
\hline Automatic translators (e.g., Google Translate) & 1.17 & 1.44 \\
\hline
\end{tabular}

As we can see, almost all kinds of resources are generally consulted more often by TLBs than by TSBs. The most significant difference (ANOVA $p$-value $=.000$ ) lies in the use of parallel texts. This may be justified by the fact that TLBs have been trained to use these resources, which can help them adapt to receivers' norms and conventions (Montalt Resurrecció 2005, 23), and understand how communication in the target community of experts (to which they do not belong) works.

Other significant differences are found in the following resources: advice from subject-matter experts (ANOVA $p$-value $=.002$ ), advice from other colleagues (ANOVA $p$ value $=.007)$, medical portals $($ ANOVA $p$-value $=.001)$, and biomedical search engines

\footnotetext{
${ }^{8}$ We refer to the Diccionario de términos médicos (Dictionary of medical terms) by the Spanish Royal National Academy of Medicine.

${ }^{9}$ We refer, for example, to the templates provided by the European Medicines Agency (EMA).

${ }^{10}$ We refer to the International Classification of Diseases (ICD), created by WHO.

${ }^{11}$ We refer to the International Nonproprietary Names (INN), a list of generic names for all pharmaceutical substances provided by WHO.
} 
(ANOVA $p$-value $=.022)$. Most of these resources are generally used for solving terminological and conceptual doubts, which are precisely those that present more difficulties to TLBs (see section 3.2.7).

At the bottom of the list, far below all the other resources, we find automatic translators. TSBs use them significantly more often than TLBs do (ANOVA $p$-value $=.015$ ), which may be explained by the fact that, unlike TLBs, they have not received training about the possibilities and limits of these resources. In any case, the use of these tools is so unusual among professional translators that we cannot consider this result to be indicative of a substantial socio-professional trait.

\subsubsection{Self-taught training}

Throughout their careers, the vast majority of respondents (92\%) have found themselves having to further their training to make up for possible shortcomings when it came to undertaking medical translations, and self-taught training (that is, learning about a subject without receiving formal training) was the option chosen by the majority (60\%). Figure 13 shows that the academic profile also affects the purpose for which translators decided to teach themselves.

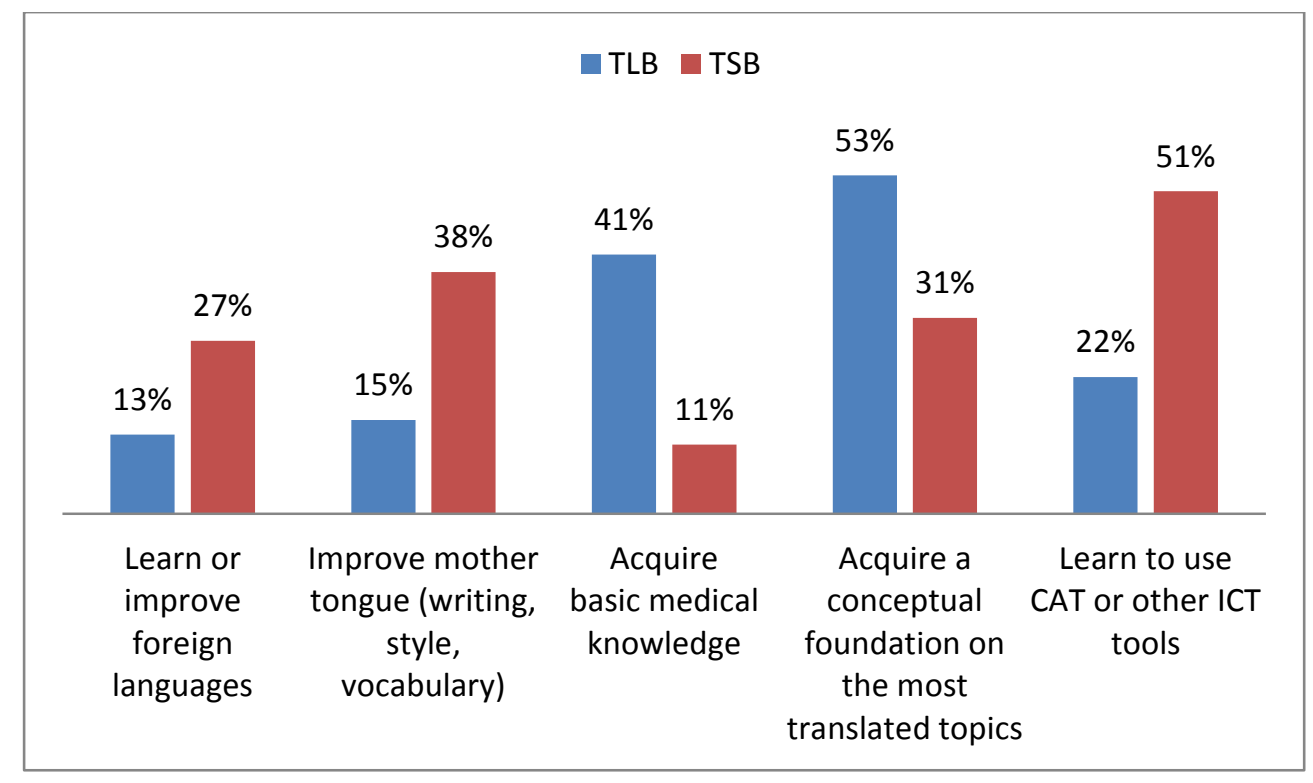

Figure 13. Aims of self-taught training

As regards linguistics aspects (the first two groups of bars), we can see that TSBs significantly needed to provide themselves with further additional self-taught training than did TLBs, especially in aspects such as improving writing, style or vocabulary in the mother tongue $($ Chi-squared $p$-value $=.001)$, but also in learning or improving foreign languages 
(Chi-squared $p$-value $=.026)$. As for conceptual issues (third and fourth groups of bars), the results show exactly the opposite. The difference between TLBs and TSBs, which is also statistically significant, is very pronounced, especially as regards acquiring basic conceptual medical knowledge (Chi-squared $p$-value $=.000)$. TSBs also needed to acquire basic medical knowledge about the topics they most often translated, but the percentage was much lower than in TLBs (Chi-squared $p$-value $=.008)$. Finally, regarding technological aspects, TSBs are those who most needed self-taught training to learn to use CAT or other ICT tools (Chisquared $p$-value $=.000$ ). These results suggest that TSBs are not so accustomed to employing technological tools, possibly because of the training they have received.

Therefore, it seems that TSBs have mainly linguistic and technological shortcomings, whereas TLBs' deficiencies tend to be of a conceptual kind. This result corroborates the findings presented in section 3.2.7.

\subsubsection{Collaboration with other professionals to review their medical translations}

Thirty-seven percent of the translators in the study sample mentioned having collaborated with colleagues or experts on a given subject to have their medical translations reviewed. There are two main reasons why translations are usually sent to be reviewed: to review specialised conceptual, terminological and phraseological aspects; and to review wording or style aspects.

Figure 14 shows that, if compared with TSBs, more TLBs in our sample collaborate with other professionals to have their translation of concepts, terminology and phraseology reviewed (Chi-squared $p$-value $=.074)$. This difference, although far less pronounced, is inverted when the aim is to review the wording or style of translations since TSBs generally use this service more often (Chi-squared $p$-value $=.173$ ).

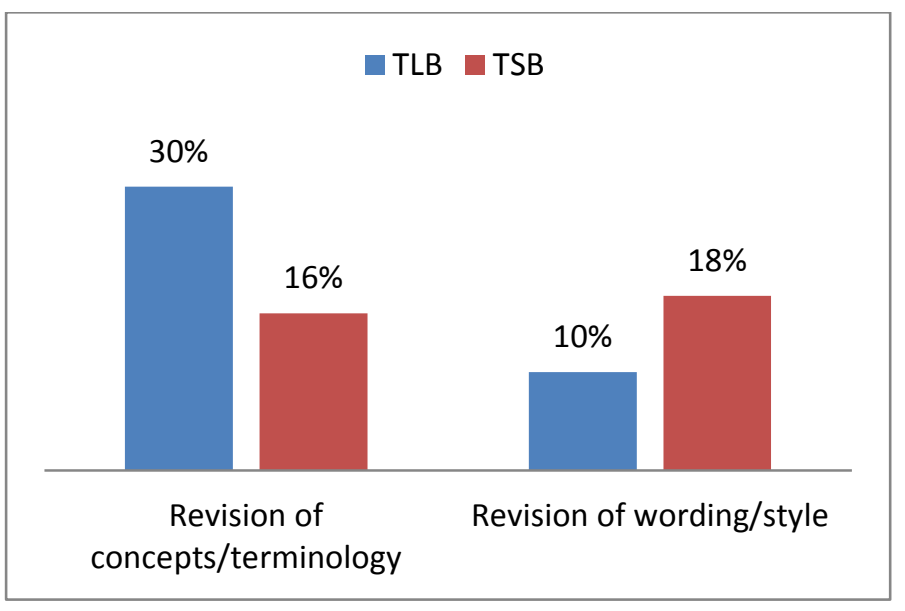

Figure 14. Reasons for having their medical translations reviewed 
As the $p$-values show, these results are not statistically significant (they could be explained by chance), although they are coherent with those related to self-taught training, which are indeed significant (see section 3.2.9), and also with the fact that advice from subject-matter experts is significantly more frequently used by TLBs (see section 3.2.8).

\subsection{Summary of the results}

By way of conclusion, Table 3 below summarises the main differences found between TLBs and TSBs for all the study variables. The differences that are not statistically significant are referred to as "non-significant results."

Table 3. Summary of the differences between TLBs and TSBs

\begin{tabular}{|c|c|c|}
\hline & TLB & TSB \\
\hline $\begin{array}{l}\text { Academic } \\
\text { qualification }\end{array}$ & $\begin{array}{l}\text { Translation and Interpreting is } \\
\text { the most frequent } \\
\text { qualification. } \\
\text { Over half the respondents have } \\
\text { a postgraduate degree. }\end{array}$ & $\begin{array}{l}\text { Medicine and Biology are the } \\
\text { most frequent qualifications. } \\
\text { Over half the respondents have } \\
\text { a postgraduate degree. }\end{array}$ \\
\hline Employment status & Mostly freelancers. & Mostly freelancers. \\
\hline Age and gender & $\begin{array}{l}\text { Mean age of } 41 \text { years. } \\
\text { The vast majority are women. }\end{array}$ & $\begin{array}{l}\text { Mean age of } 49 \text { years. } \\
\text { Balanced proportion of men } \\
\text { and women. }\end{array}$ \\
\hline Years of experience & $\begin{array}{l}41 \% \text { have more than } 10 \text { years } \\
\text { of experience. }\end{array}$ & $\begin{array}{l}73 \% \text { have more than } 10 \text { years } \\
\text { of experience. }\end{array}$ \\
\hline $\begin{array}{l}\text { Access to the medical } \\
\text { translation field }\end{array}$ & $\begin{array}{l}\text { Mostly for their interest in } \\
\text { medicine and related sciences. }\end{array}$ & Mostly by chance. \\
\hline $\begin{array}{l}\text { Percentage of work } \\
\text { that entails medical } \\
\text { translation and } \\
\text { combination with } \\
\text { other activities }\end{array}$ & $\begin{array}{l}26 \% \text { exclusively do medical } \\
\text { translations. The majority } \\
\text { combines these with other } \\
\text { translation types. }\end{array}$ & $\begin{array}{l}55 \% \text { exclusively do medical } \\
\text { translations. The rest combines } \\
\text { them mainly with other } \\
\text { translation types or with the } \\
\text { practice of medicine. }\end{array}$ \\
\hline $\begin{array}{l}\text { Other types } \\
\text { translated }\end{array}$ & $\begin{array}{l}\text { All translation types, } \\
\text { especially technical, } \\
\text { commercial and legal. }\end{array}$ & $\begin{array}{l}\text { Mostly scientific and technical. } \\
\text { No interpreting or literary } \\
\text { translation. }\end{array}$ \\
\hline Customers & $\begin{array}{l}\text { All customer types. } \\
\text { Non-significant results also }\end{array}$ & $\begin{array}{l}\text { All customer types. } \\
\text { Non-significant results also }\end{array}$ \\
\hline
\end{tabular}




\begin{tabular}{|c|c|c|}
\hline & $\begin{array}{l}\text { show that a higher proportion } \\
\text { than TSBs works for } \\
\text { translation agencies that are } \\
\text { not specialised in the medical- } \\
\text { healthcare sector, and for } \\
\text { individuals. }\end{array}$ & $\begin{array}{l}\text { show that a higher proportion } \\
\text { than TLBs work for } \\
\text { pharmaceutical laboratories } \\
\text { and for translation agencies } \\
\text { that are specialised in the } \\
\text { medical-healthcare sector. }\end{array}$ \\
\hline Texts genres & $\begin{array}{l}\text { A wide variety of medical } \\
\text { genres. } \\
\text { Non-significant results also } \\
\text { show that a higher proportion } \\
\text { than TSBs translates genres } \\
\text { that address the general public } \\
\text { and genres that can be found } \\
\text { in other translation types. }\end{array}$ & $\begin{array}{l}\text { A wide variety of medical } \\
\text { genres, although they translate } \\
\text { significantly more textbooks } \\
\text { than TLBs. } \\
\text { Non-significant results also } \\
\text { show that a higher proportion } \\
\text { than TLBs translates the genres } \\
\text { that address specialists. }\end{array}$ \\
\hline $\begin{array}{l}\text { Main difficulties } \\
\text { encountered }\end{array}$ & $\begin{array}{l}\text { More difficulties of a } \\
\text { conceptual and terminological } \\
\text { nature (e.g., understanding } \\
\text { specialised concepts, using the } \\
\text { phraseology and forms of } \\
\text { expressions employed by } \\
\text { target readers, etc.). }\end{array}$ & $\begin{array}{l}\text { More difficulties in translating } \\
\text { cultural asymmetries (non- } \\
\text { significant result). }\end{array}$ \\
\hline $\begin{array}{l}\text { Documentation } \\
\text { resources used }\end{array}$ & $\begin{array}{l}\text { Greater use of parallel texts, } \\
\text { and advice from subject-matter } \\
\text { experts and colleagues. }\end{array}$ & $\begin{array}{l}\text { Greater use of automatic } \\
\text { translators (although the use of } \\
\text { this tool is minimal in both } \\
\text { groups). }\end{array}$ \\
\hline Self-taught training & $\begin{array}{l}\text { To acquire basic conceptual } \\
\text { medical knowledge and } \\
\text { knowledge about the most } \\
\text { frequently translated topics. }\end{array}$ & $\begin{array}{l}\text { To improve writing, style or } \\
\text { vocabulary in their mother } \\
\text { tongue, and to learn to use } \\
\text { CAT or other ICT tools. }\end{array}$ \\
\hline $\begin{array}{l}\text { Collaboration with } \\
\text { other professionals to } \\
\text { review their } \\
\text { translations }\end{array}$ & $\begin{array}{l}\text { Need to have conceptual and } \\
\text { terminological aspects } \\
\text { reviewed more frequently than } \\
\text { TSBs (non-significant result). }\end{array}$ & $\begin{array}{l}\text { Need to have the wording or } \\
\text { style of the translation } \\
\text { reviewed more frequently than } \\
\text { TLBs (non-significant result). }\end{array}$ \\
\hline
\end{tabular}

\section{Discussion}

As we have seen, access to professional medical translators has allowed us to obtain empirical data about a number of aspects of their profile and medical translation practice. 
Based on these data, we have explored the possible differences between translators with a linguistic background and those with a scientific-medical background.

First of all, and as expected, the study confirms that medical translators do not have a uniform academic background. Although the TLB group predominates, the high percentage of professionals who have studied Medicine or Biology proves how permeable medical translation is to different scientific academic profiles. This could be due to the fact that having thematic knowledge, which may be the competitive advantage of TSBs, is a decisive factor. In line with this, it would be interesting to study if access to the translation profession by experts in the field also occurs to such a great extent in other translation areas where thematic knowledge is of paramount importance, such as legal or technical translation.

The fact that Translation Studies is a young discipline could explain why TSBs have more years of experience. Professionals with a scientific background would have first occupied the medical translation niche, possibly because its market demand was not satisfied by translation-trained translators. As suggested in section 1, the inexistence of university programmes, until quite recently, which specifically aimed to satisfy the requirements of the translators seeking a specialisation in the medical field would further justify this result.

The way that TSBs have accessed the medical translation field is also proof that the translation profession is not their natural career. Hence, although it seems that the medical/scientific qualification would grant translators easier access to translation practice, it would also restrict it, as most TSBs limit their translation activities to medical texts or, at the most, to specialities that are thematically related to their graduate degrees, as shown in section 3. TLBs, however, carry out translations from a wider variety of fields, possibly because their academic qualification has enabled them to be more prepared to face other types of translation.

The aspects that both groups find most difficult to solve, their self-taught training needs, and even the documentation resources they use (especially TLBs), also give us an idea of the strengths and weaknesses of their respective graduate degrees when translating medical texts. Therefore, as we have seen, TLBs perceive that their main weaknesses are conceptual and terminological aspects, while TSBs report having more limitations when using technological tools or mastering their mother tongue. The fact that they are all aspects not dealt with in Translation/Philology and in Medicine/Biology degrees, respectively, suggests that both profiles have attempted to acquire the competences that their respective graduate qualifications would not have provided either by means of self-teaching or postgraduate courses (remember that the proportion of translators with postgraduate training in both groups 
was quite high). Accordingly, the benefits of offering specialised postgraduate courses in medical translation seem quite evident. These programmes could include a certain number of different training modules, depending on students' academic background, so as to satisfy the specific needs of each group of translators.

The study has also revealed some non-significant trends for either the customers they work for or the genres they translate. In these cases, differences between groups were not statistically significant and could be explained by chance. However, the data obtained (the TSBs in our sample translate genres that address specialists to a greater extent and work more for 'specific' customers of the medical sector) are coherent with other aspects of the study. Therefore, future studies that are aimed at a larger population could shed some light on the possible connections between academic profile and these variables, and could help determine if, for example, the conceptual knowledge acquired by TSBs in their degrees would have better prepared them to face more specialised genres and customers.

Apart from all the differences discussed, this study provides evidence that medical translators share a series of characteristic socio-professional traits. First of all, many of them have ample experience in the field; secondly, they work for a wide variety of customers, of whom some of the most important are translation agencies that are specialised in the medical field and pharmaceutical laboratories. This variety is also reflected in the genres they translate (among which those of the pharmaceutical and research sectors predominate) and, in turn, in the variety of documentation resources they use, which proves the wide range of resources that are needed to solve medical translation problems. Finally, many translators work exclusively in this specialised area, which confirms that medical translation provides professionals with enough work for them to earn a living without having to diversify their efforts. All these findings corroborate, in turn, the extent of medical translation, its widespread demand on the market, and the job opportunities it offers to professionals with a variety of profiles.

\section{Conclusions and future work}

This paper has explored the differences between TLBs and TSBs based on the results of an empirical descriptive study using surveys carried out with medical translators. The study has allowed us to collect quantitative data about differences between groups, without making any judgements as to which professional is better suited to carry out medical translations. This aspect distinguishes our work from most of the studies referred to in section 1, which focus 
on the medically knowledgeable linguist versus linguistically knowledgeable medical professional dichotomy, and make statements about the characteristics of the two profiles based merely on intuition or personal experience. This study has also provided rigorous socio-professional information about the group of translators who satisfy the needs of one of the most prosperous areas in the professional translation field.

Although the limitations of the sampling method prevent us from generalising our findings beyond the sample itself, we feel that the response rate, together with the considerable number of responses collected (167 in all), have enabled us to gain an approximate idea of the English-to-Spanish medical translators' profile, and also of the differences between TLBs and TSBs, both those that are statistically significant and those that are not. We should bear in mind, however, that part of these findings come from the translators' views and perceptions about their professional practice, and these might differ from what they actually do to a certain extent. Finally, we should also take into account that our study is linked to just one language pair (English-Spanish) and that the situation regarding medical translation practice in other language combinations might be completely different.

As for future work, we plan to explore the socio-professional differences more in depth by designing specific studies aimed at a larger sample of medical translators and based on the results obtained - remember that exploring these differences was not the primary objective of the survey - and their possible influence on the design of medical translator training. Another line of research that remains open is to carry out similar surveys, but ones whose specific targets are employers and customers, in order to analyse the value they give to possessing a certain kind of academic qualification when seeking a medical translator.

\section{References}

Albarrán Martín, Reyes. 2012. Traducción y medicina: aspectos epistemológicos e interdisciplinares para la formación de traductores especializados en ciencias de la salud. PhD diss. Universidad de Salamanca.

Alfaro, Vicente. 2009. "El redactor de textos médicos en las empresas farmacéuticas." In La redacción médica como profesión. Qué es y qué hace el redactor de textos médicos, edited by Fernando Rico Villademoros and Vicente Alfaro, 7-20. Barcelona: Fundación Dr. Antonio Esteve. 
Balliu, Christian. 1998. "Enseñanza de la traducción médica a futuros traductores: enfoque teórico y práctico.” In Félix Fernández and Ortega Arjonilla 1998, 79-88.

Bloom, Benjamin. 1985. Developing Talent in Young People. New York: Ballantine.

Cerezo Merchán, Beatriz. 2012. La didáctica de la traducción audiovisual en España: un estudio de caso empírico-descriptivo. PhD diss. Universitat Jaume I.

Dam, Helle. V., and Karen Korning Zethsen. 2010. "Translator Status. Helpers and Opponents in the Ongoing Battle of an Emerging Profession.” Target 22 (2): 194-211.

Ericsson, K. Anders. 1996. The Road to Excellence. The Acquisition of Expert Performance in the Arts and Sciences, Sports, and Games. Mahwah, NJ: Lawrence Erlbaum.

Félix Fernández, Leandro, and Esperanza Alarcón Navío. 1998. "La terminología especializada y el léxico común en el marco de la traducción de textos médicos de divulgación.” In Félix Fernández and Ortega Arjonilla 1998, 169-186.

Félix Fernández, Leandro, and Emilio Ortega Arjonilla, eds. 1998. Traducción e interpretación en el ámbito biosanitario. Granada: Comares.

Fischbach, Henry, ed. 1998. Translation and Medicine. Amsterdam: John Benjamins.

Gallardo San Salvador, Natividad. 1996. “Aspectos metodológicos de la traducción científica." In La enseñanza de la traducción, edited by Amparo Hurtado Albir, 141159. Castelló de la Plana: Universitat Jaume I.

Gile, Daniel. 1986. "La traduction médicale doit-elle être réservée aux seuls traducteursmédecins ? Quelques réflexions." Meta 31 (1): 26-30.

Gouadec, Daniel. 2007. Translation as a Profession. Amsterdam: John Benjamins.

Gutiérrez Rodilla, Bertha M. 1998. La ciencia empieza en la palabra. Análisis e historia del lenguaje científico. Barcelona: Península.

Hernández Sampieri, Roberto, Carlos Fernández Collado, and Pilar Baptista Lucio. 2010. Metodología de la investigación. México: McGraw-Hill Interamericana.

Instituto Cervantes. 2014. “El español: una lengua viva. Informe 2014.” In El español en el mundo. Anuario del Instituto Cervantes 2014, edited by Instituto Cervantes. Madrid: Instituto Cervantes, Boletín Oficial del Estado. http://cvc.cervantes.es/lengua/anuario/anuario_14/default.htm.

Jensen, Matilde Nisbeth, and Karen Korning Zethsen. 2012. “Translation of Patient Information Leaflets - Trained Translators and Pharmacists-cum-Translators: A Comparison." Linguistica Antverpiensia 11: 31-49.

Kelly, Dorothy. 2002. "Un modelo de competencia traductora: bases para el diseño curricular." Puentes 1: 9-20. 
Kumar, Ranjit. 2014. Research Methodology. A Step-by-Step Guide for Beginners. $4^{\text {th }}$ ed. London: Sage.

Kuznik, Anna, Amparo Hurtado Albir, and Anna Espinal Berenguer. 2010. "El uso de la encuesta de tipo social en Traductología. Características metodológicas.” Monti: Monografías de Traducción e Interpretación 2: 315-344.

Lee-Jahnke, Hannelore. 1998. "Training in Medical Translation with Emphasis on German." In Fischbach 1998, 81-91.

Lee-Jahnke, Hannelore. 2001. "L’enseignement de la traduction médicale : un double défi ?" Meta 46 (1): 145-153.

Lee-Jahnke, Hannelore. 2005. “Teaching Medical Translation: An Easy Job?” Panace@ 6 (20): 81-84.

Li, Defeng. 2000. "Tailoring Translation Programs to Social Needs: A Survey of Professional Translators." Target 12 (1): 127-149.

Mayor Serrano, Mª Blanca. 2003. "La formación de traductores médicos en España: ¿otra asignatura pendiente?" Trans 7: 131-136.

Mayor Serrano, Ma Blanca. 2006. "Hacia la especialización en los estudios de Traducción." Panace@ 7 (23): 81-87.

Mayoral Asensio, Roberto. 2001. Aspectos epistemológicos de la traducción. Castelló de la Plana: Universitat Jaume I.

Montalt Resurrecció, Vicent. 2005. "El género como espacio de socialización del estudiante de traducción científico-técnica." In El género textual y la traducción. Reflexiones teóricas y aplicaciones pedagógicas, edited by Isabel García Izquierdo, 19-36. Bern: Peter Lang.

Montalt Resurrecció, Vicent. 2007. “La enseñanza virtual de la traducción médica en el Espacio Europeo de Educación Superior (EEES).”Panace@ 9 (26): 213-219.

Montalt Resurrecció, Vicent. 2010. "Medical Translation and Interpreting." In Handbook of Translation Studies. Volume 2, edited by Yves Gambier and Luc van Doorslaer, 79-82. Amsterdam: John Benjamins.

Montalt Resurrecció, Vicent, and Maria González-Davies. 2007. Medical Translation Step by Step. Learning by Drafting. Manchester: St. Jerome.

Mugüerza Pecker, Pablo A. 2012. Manual de traducción inglés-español de protocolos de ensayos clínicos. Barcelona: Fundación Dr. Antonio Esteve.

Muñoz Martín, Ricardo. 2014. "Situating Translation Expertise: A Review with a Sketch of a Construct." In The Development of Translation Competence: Theories and 
Methodologies from Psycholinguistics and Cognitive Science, edited by John W.

Schwieter and Aline Ferreira, 2-56. Newcastle: Cambridge Scholars.

Muñoz-Miquel, Ana. 2014a. "El perfil y las competencias del traductor médico desde el punto de vista de los profesionales: una aproximación cualitativa." Trans. Revista de Traductología 18: 163-181

Muñoz-Miquel, Ana. 2014b. El perfil del traductor médico: análisis y descripción de competencias específicas para su formación. $\mathrm{PhD}$ diss. Universitat Jaume I.

Muñoz-Miquel, Ana. 2016. "Bridging the Gap between Professional Practice and University Training through Socio-professional Research: The Case of Medical Translation.” In From the Lab to the Classroom and Back Again: Perspectives on Translation and Interpreting Training, edited by Celia Martín de León and Víctor González-Ruiz, 257294. Frankfurt am Main: Peter Lang.

Navarro, Fernando A. 2001. "El inglés, idioma internacional de la medicina. Causas y consecuencias de un fenómeno actual.” Médico Interamericano 20: 16-24.

Navarro, Fernando A., and Francisco Hernández. 1997. “Anatomía de la traducción médica.” In Lecciones de teoría y práctica de la traducción, edited by Leandro Félix Fernández and Emilio Ortega Arjonilla, 137-162. Málaga: Universidad de Málaga.

Navascués Benlloch, Ignacio, and Angel Hernando Saudan. 1998. "El médico traductor de textos médicos.” In Félix Fernández and Ortega Arjonilla 1998, 147-158.

O’Neill, Marla. 1998. "Who Makes a Better Medical Translation: The Medically Knowledgeable Linguist or the Linguistically Knowledgeable Medical Professional? A Physician’s Perspective.” In Fischbach 1998, 69-80.

Pilegaard, Morten. 1997. “Translation of Medical Research Articles.” In Text Typology and Translation, edited by Anna Trosborg, 159-184. Amsterdam: John Benjamins.

Pym, Anthony, François Grin, Claudio Sfreddo, and Andy L. J. Chan. 2012. The Status of the Translation Profession in the European Union (DGT/2011/TST). Final Report.

Luxembourg: European Commission. http://ec.europa.eu/dgs/translation/publications/studies/translation_profession_en.pdf.

Rea, Louis M., and Richard A. Parker. 2005. Designing and Conducting Survey Research. A Comprehensive Guide. $3^{\text {rd }}$ ed. San Francisco, CA: Jossey-Bass.

Robertson, Sally. 1998. "Right in the Middle of It All: The US National Institutes of Health Translation Unit - An Interview with Unit Head, Ted Crump.” In Fischbach 1998, 131146. 
Rodríguez Sabiote, Clemente, José Gutiérrez Pérez, and Teresa Pozo Llorente. 2007.

Fundamentos conceptuales y desarrollo práctico con SPSS de las principales pruebas de significación estadística en el ámbito educativo. Granada: GEU.

Rouleau, Maurice. 1994: La traduction médicale. Une approche méthodique. Montreal: Linguatech.

Sachinis, Michail. 2011. Curriculum Renewal in Greek Taught Postgraduate Translation Courses: Aligning Student Needs and Translation Market Requirements. PhD diss. Imperial College London.

Saldanha, Gabriela, and Sharon O'Brien. 2013. Research Methodologies in Translation Studies. Manchester: St. Jerome.

Shreve, Gregory M. 2006. “The Deliberate Practice: Translation and Expertise.” Journal of Translation Studies 9 (1): 27-42.

Valderrey Reñones, Cristina. 2012. "Thematic Competence in Law: The Non-lawyer Translator.” In Iberian Studies on Translation, edited by Isabel García Izquierdo, and Esther Monzó Nebot, 53-69. Bern: Peter Lang.

Wakabayashi, Judy. 1996. "Teaching Medical Translation.” Meta 41 (3): 356-365.

Wood, Michael. 2003. Making Sense of Statistics. A Non-mathematical Approach. Basingstoke: Palgrave.

Wright, Sue Ellen, and Leland D. Wright, Jr. 1993. Scientific and Technical Translation. Amsterdam: John Benjamins.

Author's address

Ana Muñoz-Miquel

Universitat Jaume I

Av. Sos Baynat, s/n

12071 Castelló de la Plana

Spain

munoza@uji.es 